\title{
ETHICAL DECISION-MAKING IN TURKISH PUBLIC ADMINISTRATION AND POLICY ${ }^{1}$
}

\author{
Mısra Ciğeroğlu Öztepe \\ Dr., Assistant Professor at Pamukkale University, Faculty of Economics and Administrative \\ Sciences, Department of Political Science and Public Administration. \\ Address: Pamukkale University, Department of Political Science \\ and Public Administration, Denizli, Turkey \\ E-mail: mcigeroglu@pau.edu.tr

\section{Onur Kulaç} \\ Dr., Assistant Professor at Pamukkale University, Faculty of Economics and Administrative \\ Sciences, Department of Political Science and Public Administration. \\ Address: Pamukkale University, Department of Political Science \\ and Public Administration, Denizli, Turkey \\ E-mail: onurkulac@yahoo.com / okulac@pau.edu.tr
}

\begin{abstract}
Defined in the simplest and the most comprehensive framework, decision-making is the process of choosing between alternatives, and it is affected by various factors. Ethics, which is regarded as one of the significant elements among these factors, influences the decision-making process at organisational and individual levels. The subjects of ethics and ethical decision-making are becoming highly crucial in public policy making and implementation processes. Moreover, topics such as the circumstances that have an impact on the decisions of public administrators, and the ethical codes or institutions that help public administrators are major research areas in recent public administration literature. It is within this framework that this paper analyses the efforts to create an ethical policy, which will contribute to the ethical decision-making process of the public administrators in Turkey in terms of legislation, institutional dimension and ethical codes. This study reveals that even though Turkey has taken promising steps to generate an ethical system for public administration and service, there are still essential points to be reassessed regarding the expected transformation in combating corruption and unethical behaviours.
\end{abstract}

Keywords: Public Administration and Policy; Ethics; Decision-making; Turkey.

Citation: Ciğeroğlu Öztepe, M. \& Kulaç, O. (2019). Ethical Decision-Making in Turkish Public Administration and Policy. Public Administration Issue, Special Issue I (electronic edition), pp. 62-78 (in English); DOI: 10.17323/1999-5431-2019-0-5-62-78.

\footnotetext{
1 This study has benefited from the 1st author's (Misra Ciğeroğlu Öztepe) doctoral dissertation, completed at Ankara University in 2013.
} 


\section{Introduction}

Shown to be among the chief problems experienced within the public administration discipline, the increase in corruption and degeneration has brought the topic of "ethics" to the fore with regards to discipline and public policy studies. Especially since the 1970s, the concept of "public administration ethics" and the implementations regarding this concept have come to be debated frequently, and since the 1980s and 1990s, the concept has become tremendously popular in public administration discipline and found a place for itself in the reform attempts that are happening in many cities. One of the most important factors in public administration ethics is decision-making. When public administrators are doing their job, they have to make certain decisions and act in accordance with their decisions. Hence, decision-making plays a crucial role in the functioning of public administration and the public policy creation processes.

In its traditional sense, decision-making can be defined as choosing one option among many alternatives; and it is a requisite in the beginning of the public administration process no matter its level. In fact, the decision-making models in public policy have a noteworthy impact on the public policy process, which is comprised of a variety of stages. Thus, the alternatives are evaluated through the chosen decision-making process or approach, and the targets are set to be achieved as such. The decision-making process also holds importance for the administration that is implementing the policies and the public administrators. Public administrators especially have to be careful when they are making decisions so as to comply with the ethical principles and values and act accordingly. In this framework, it is evident that there are various theories and models within philosophy, public administration and administrative sciences literature.

The fundamental purpose of this study is to examine the ethical system in Turkey that supports civil servants' ethical decision-making process in a descriptive way. In this context, this study is structured into three parts, starting with the analysis of the ethical decision-making process in public administration and public policy. Later on, we will touch upon the literature on ethical decision-making. Finally the legal arrangements that contributed to the decision-making process in Turkish public administration, the organisational structure and the ethical principles and codes are presented.

\section{Decision-Making in Public Policy and Administration}

In the decision-making process, tremendous key factors and circumstances are considered in an effort to have desired decisions. The decision-making process is conducted and maintained at different levels, such as individual, organisational and governmental. On each level, various conceptual models and approaches are utilised as a purposeful action. Especially at the governmental level, the decisionmaking process is highly crucial so as to have efficient and functional public policies. In this manner, public policy can be defined as the goal-oriented actions of the governments instead of random occurrences (Anderson, 1979). Furthermore, public policy decision-making, which is also described as a political process 
(Howlett \& Ramesh, 1995), is most likely to be taken into account on the governmental level as a result of social necessities (Knoepfel et al., 2007). As social needs and problems are related to numerous policy fields, the extent of the public policy fields is quite broad (Hogwood \& Gunn, 1984, p. 13; Ylldı \& Sobac1, 2013, p. 17) and many public policies are put forth on a macro level such as security, culture, development, education, environment, energy, and defence. The decisions made in this respect have an impact on the majority of the citizens directly or indirectly (Birkland, 2005, p. 20). Decision-making is overwhelmingly significant in the process of policy formulation and implementation. In this context, many countries make relevant policies in order to struggle with unethical behaviours and activities. Ethics, which is a macro level policy, consists of the organisations in public administration, civil servants, citizens, and private sector and non-governmental organisations. There are certain tools to reflect these policies moving into implementation. Therefore, laws, codes of ethics, and institutional structures are used as tools so as to generate an ethical policy and framework.

Even at the individual level, diversified models are put forth and developed in the public policy literature regarding decision-making processes. These models can be summed up as the Rational Model (Simon, 1972; Anderson, 1979; Hill, 1997; Gosling, 2004; Dye, 2008), the Incremental Model (Lindblom, 1959, 1979; Nice, 1987; Howlett \& Ramesh, 1995; Birkland, 2005; Stewart, 2009), the Mixed Model (Etzioni, 1967), the Garbage Can Model (Cohen et al., 1972; Browning, 2006), and the Institutional Rational Choice Model (Ostrom, 1991, 2007). In each decision-making model, different dynamics and the aspects are taken into account so as to come up with a promising process. Especially in the rational decision-making model, possible prospective policy and decision alternatives are scrutinised in a comprehensive manner. However, as stated by Simon (1972) with the bounded rationality concept, evaluating all the alternatives is often not feasible for the policy makers. Therefore, many of the major options and the outputs are not taken into account through applying a muddling-through method (Hill, 1997, p. 10).

In public policy decision-making process, numerous essential actors have a key role and are categorised into three groups. Official, unofficial and international actors have massive impacts on public policy decisions. Official actors in central or local governments are responsible for the generation and maintenance of the public policies. By the introduction of the new management and planning techniques in public institutions, civil servants are under more pressure while making decisions about their tasks and about the policies of the relevant public institutions. In this context, civil servants, who are also called "Street- Level Bureaucrats" by Lipsky (1980), have certain duties in the implementation process of the public policies as well. As put forth by Knoepfel et al. (2007, p. 65), there are some sources of public policy for the effective decision-making and the implementation. Personnel is one of the most fundamental public policy sources, and the public institutions at every level seek to employ competent personnel for the purpose of having a smooth workflow. Thus, vocational experience and knowledge of the public personnel are notably significant in decision-making and implementation processes. 
As unofficial actors in public policy process, individuals have a limited effect on every stage of policy process. In underdeveloped and developing countries, the practices of public engagement are considerably low in number and decisions are generally made by official actors. Nevertheless, with the rapid transformation in public administration and policy, unofficial functional actors such as think tanks and pressure groups have started to influence the process of decision-making. In this fashion, individuals have an opportunity to be involved in the decisionmaking process by taking part in think tanks or pressure groups. Furthermore, the spread of the governance concept among countries, especially in the last two decades, has made significant contributions to the decision-making process. In this manner, representatives of private sector and the non-governmental organisations (NGOs) have become the stakeholders in most stages of public policy. On the other hand, with the rise of globalisation and international relations, international actors and institutions such as the European Union (EU), the United Nations (UN), the International Monetary Fund (IMF), and the World Bank (WB) have an increasing impact on the domestic and foreign policies of countries. In this context, most countries formulate their policies and decisions according to the recommendations of relevant international actors. Therefore, the decision-making process in public administration and policy in most countries is shaped in accordance with international actors.

\section{Literature Analysis of Ethical Decision-Making}

In the most general terms, it can be said that decision-making process, which can be defined as a preference among the alternatives, is influenced by many factors. In fact, the decision is directly related to the decision maker. This interest is founded on many factors such as psychological factors, environmental factors, social and organisational principles, technological developments, laws and regulations. Ethics is a fundamental element in these psychological factors (Solak \& Sancak, 2015, p. 314). Expressed in moral philosophy in its most general sense which goes back to its ancient Greek origins, ethics is also defined by Gündoğdu $(1999$, p. 30) as a discipline that examines the values of human beings from angles such as what is "good and "bad" and how to understand "right" and "wrong". Ethics explores the values, norms, and rules that form the basis of individual and social relationships established by people from ethical aspects such as right-wrong or good-bad and basically attempts to determine the standards of right and wrong behaviour, values or attitudes (Pehlivan, 1997, p. 1). Individuals benefit from their true-false perceptions, beliefs, values, and the social and personal norms they have in decision-making processes in their personal and business life. Therefore, the concept of ethics is highly significant in terms of individual and organisational decision-making processes.

Daft (2010, p. 130) emphasises that ethics is a crucial issue both organisationally as well as individually, and states that managers often encounter situations where they cannot determine what is right. It is extremely difficult for managers to be able to make ethical decisions in such situations. According to Jones (1991, p. 367), an ethical decision is defined as "a decision that is both legal and morally acceptable to the larger community". Managers in a decision maker's position, 
whether in private or public organisations, should act in accordance with factors such as equality, justice, impartiality and respect for individual rights, and include these elements in the decision-making process (Fritzsche \& Becker, 1984, p. 167). This situation makes the concept of "ethical decision-making" remarkably essential in terms of the individuals working in the organisation, the managers, the organisation itself and society.

According to Trevino (1986, p. 601), understanding organisational ethics is crucial for the development of organisational science. There are ethical dilemmas in organisations in which more than one stakeholder, interests and values are in conflict and the laws are not obvious. Ethical dilemmas often arise when values conflict with what is right or wrong. Wood $(2001$, p. 10) states that ethical dilemmas or problems are difficult situations that need to be solved with alternatives that are equally unsatisfactory, and it will be easier to make decisions in challenging situations through the use of ethical principles and approaches. Therefore, the significance of ethical decision-making becomes even more evident when managers' decisions and actions to resolve these ethical dilemmas are thought to cause very essential social consequences, particularly in the areas of health, safety and welfare that concern consumers, employees, and society (Trevino, 1986, p. 601).

Ethical decision-making processes are closely related to ethical philosophy and theories. Establishing a link between ethical theories and the behaviour of managers is the basis for a change in behaviours in a more ethical way for the benefit of society (Fritzsche \& Becker, 1984, p. 166). Approaches that form the basis of ethical decision-making processes can be listed as the Utilitarian Approach, the Egoistic/Individualism Approach, the Duty-Based Approach, the Rights Approach, the Fairness/Justice Approach, the Common Good Approach and the Virtue Approach (Daft, 2010, pp. 132-134; Cavanagh et al., 1981, pp. 365-367; Meeler, n.d). The Utilitarian Approach, the Egoistic Approach and the Common Good Approach fall under Consequentialist Theories. In the Utilitarian approach; what determines the value of moral action is the end result of action and the benefit it brings to the situation with this result. In this approach, decision makers need to anticipate the impact of existing alternatives on all parties involved and choose the alternative that will serve the greatest pleasure or benefit (Cavanagh et al., 1981, p. 365). According to the Egoistic/ Individualism Approach, if the decision or behaviour in decision-making serves the individual's long-term interests, it is moral. Moreover, it is believed that all individual interests will ultimately turn into a collective good for everyone (Daft, 2010, pp. 132-133). The Common Good Approach focuses on the interrelated aspects of society and the moral decision or action that is shaped by a common good for the broader society in the framework of respect and compassion for those in a more vulnerable state, that is, an effort to reach that which is in everyone's best interests (Muzumara, 2018, p. 5). The Duty-Based Approach, the Rights Approach, and the Fairness/Justice Approach are non-Consequentialist Theories. The Duty-Based Approach can also be defined as deontological ethics and is most commonly associated with Immanuel Kant. According to Kant, an action or decision is not the result of moral value, but an intention behind 
action (Boatright, 2000, pp. 52-54; Kılavuz, 2003, pp. 64-66; Muzumara, 2018, pp. 5-6). The Rights Approach emphasises the fundamental rights and freedoms of individuals and acknowledges that ethical decisions are decisions that protect the rights of those affected by it (Daft, 2010, p. 133; Fritzsche \& Becker, 1984, p. 167). The Fairness/Justice Approach focuses on the distributional effects of actions or policies and emphasises that ethical decisions must be based on standards such as equity, justice, and impartiality (Rawls, 1971; Fritzsche \& Becker, 1984, p. 167). The Virtue Approach is part of agent-centred theories and advocates that ethical actions should be consistent with ideal human virtues (Boatright, 2000, pp. 62-67; Muzumara, 2018, p. 7). All these approaches emphasise different dimensions of the ethical decision-making process and form the basis for this process.

There are many models of ethical decision-making in organisations. These models have interpreted the stages and functions of ethical decision-making and the bases of ethical decisions in different ways. For example, Wood (2001, p. 10) states that using ethical principles and approaches will make it easier to make decisions in difficult situations, and cites Curtin (1979) by using basic steps of ethical decision-making in his analysis. These basic steps can be arranged as "Perception of the Problem, Identification of Ethical Components, Clarification of People Involved, Exploration of Options, and Application of Ethical Theory and Resolution/Evaluation" (Wood, 2001, pp. 7-10; Curtin, 1979). Forester-Miller and Davis (1996, pp. 1-2) emphasise that Autonomy, Justice, Beneficence, Nonmaleficence and Fidelity are the five fundamental moral principles, and when faced with an ethical dilemma they state that these principles should be taken into account first. Moreover, the stages of the ethical decisionmaking model are listed by Forester-Miller and Davis (1996, p. 2-4) as determining the problem, applying the code of ethics, identifying the nature and the dimensions of the dilemma, generating potential courses of action, considering the potential results of all choices, and choosing, implementing and evaluating the course of action. Trevino (1986), who proposed "A Person-Situation Interactionist Model" for ethical decision-making in organisations, emphasises that the model is making great use of the cognitive moral development model of Kohlberg (1969). According to Trevino (1969, pp. 602), individuals' attitude towards an ethical dilemma is shaped largely by their level of cognitive moral development. However, situational variables arising from existing business conditions or organisational culture are also very influential in the ethical decision-making process. Ethical decision-making in organisations can therefore be explained by the interaction between individual and situational components. In addition to these theories, there are fundamental studies by Cavanagh et al. (1981), Ferrell and Gresham (1985), Hunt and Vitell (1986), Bommer et al. (1987), Dubinsky and Loken (1989), Jones (1991), and Gaudine and Thorne (2001) about ethical decision- making in organisations.

When the subjects of public administrators and civil servants are taken into consideration, it is observed that the above-mentioned ethical theories and models closely influence the decision-making process of civil servants. Decisions made by public administrators are to be a mixture of professional and 
individual values, as well as the needs of public services and the public interest. In this sense, civil servants have to act in accordance with laws and regulations and have to make decisions within the scope of their own individual values and public service needs.

John Rohr, who proposed a normative model at the point of ethical decision-making for public administrators, stated that in ethical decisions, the constitution in an organisational sense could guide the high court's and regime values of existing laws; Terry L. Cooper emphasised that ethical decision-making ability is a dynamic process that can be "learned and cultured" through administrative decisions and behaviours frequently revealed to civil servants over time, and ethical decision-making skills can be acquired as ethical decisions are taken during this process; Gerald Pops and Thomas Pavlak stated that decision-making in public administration should be tied to principles and procedures based on the precondition of "justice"; Carol Lewis proposed the creation of a checklist that will help public administrators make ethically responsible decisions (Wittmer, 2001, p. 493-498). Frederickson emphasises the focus of civil servants on social equality and public interest in the decisionmaking process; Dobel identifies regime responsibility, personal responsibility and common sense as key procedures of ethical decision-making; Kathryn Denhardt defines honour, benevolence and justice as three ethical bases and stresses that public administrators must take them into account in the decisionmaking process (Van Mart, 1996, p. 526).

In terms of public personnel, decision-making is one of the most fundamental functions of public policy implementation. At this point, in addition to the legal texts such as Constitution, Law, Regulation, Directive and Circular, which guide public employees, ethical regulations are also needed. Even at this point, the need to emphasise the validity of internal auditing and external auditing at the control point of civil servants' decisions and behaviours arises, which had started between Carl Friedrich and Herman Finer as a topic of debate in the literature and continues to be a subject of controversy to this day. Accordingly, the effect of internal auditing mechanisms (represented by professional values, standards and ethics in addition to or in place of the external audits of the law at the control point of decisions and behaviours) is emphasised (Cooper, 2001, p. 5).

Essentially, civil servants have to make many tough decisions both while creating and carrying out public policies and while performing their public services; and legal arrangements and external auditing sources fall short of making these decisions and acting on them accordingly for public administrators. Legal arrangements and external audit instruments are not sufficient for public administrators to make and act on these decisions. For this reason, the existence of ethical values and occupational standards is at least as significant as legal arrangements and external control mechanisms. In this context, the existence of ethical committees and principles, standards or codes is of utmost importance as well as legal legislation at the point of ethical decisionmaking in terms of public administrators. Today, in many countries, including Turkey, it is possible to see attempts to establish an ethical system in the context of mentioned elements. 


\section{Basic Elements and Regulations Formulating the Ethical Decision-Making Process in Turkish Public Administration ${ }^{2}$}

In Turkey's public administration, unfortunately, it can be observed that unethical activities are strikingly widespread. Especially in recent years, this situation has surpassed the individual level and has become institutional, which has caused a break in citizens' confidence towards the government. Since the establishment of the Republic, especially during the period before the 1980s, public administration in Turkey can be said to have fallen into an intensive and common ethical depression especially after the second half of the 1970s. This depression is said to be not only a part of the global ethical problems of public administration, but also a result of a widespread structural and functional degeneration (Emre, 2002, p. 6). This situation has become one of the main factors that cause public administration to lose its function substantially and to be in need of reform.

It is evident that a comprehensive transformation has started to take place in Turkish public administration, especially since 2000 . The integration process in the European Union emerged as the main driving force for these public administration reforms. The most comprehensive and remarkable one among all the reform efforts made for this purpose is the "Law on Basic Principles and Restructuring of Public Administration (Number 5227) " which was shared with the public in 2003 as the "Public Administration Basic Law Bill" and which could not be put into practice. Despite not being able to be put into practice, this law can still be regarded as a turning point in the process of transforming or restructuring public administration. It is clear that the legal regulations coming into force since 2004 emphasise the key elements of Law No. 5227 and address issues such as efficiency, transparency, openness, participation, ethics, accountability, quality, contracted employment, performance audit and customer orientation in public administration. This somewhat forced the change in the public administration within the framework of EU integration studies and the demands of international organisations is aimed at ensuring good governance within public administration, especially supported by the UN, OECD, EU and WB (Balc1, 2003, p. 128; Gül \& Memişoğlu, 2007, p. 72). In this context, public administration ethics and the inclusion of public administrators in making regulations to contribute to the ethical decision-making process found its own position within the transformation that took place, and the applications and regulations related to public administration ethics as one of the key elements of ensuring good governance in Turkey has begun to be implemented.

Essentially, even though the existence of the legal regulations governing the basic rules and the behaviours to be avoided while fulfilling the public du-

\footnotetext{
2 This part of the study covers the period until Turkey changed over to the new presidential system of government after the elections held in June 2018.

3 After the stated bill was accepted as "Law on Basic Principles and Restructuring of Public Administration (Number 5227)". On August 3, 2004, it was partially vetoed by the President and sent back to the Grand National Assembly of Turkey (GNAT) to recommit some of its articles. Since then, laws containing regulations parallel to the essential elements of the mentioned regulations have come into force.
} 
ties within the Turkish public administration are in question, it can be said that the concrete steps to carry out the regulations to help civil servants specifically during ethical decision-making process have begun as of 2004. Considering the fact that there should be a well-functioning ethical infrastructure to have a wellfunctioning public administration, an attempt has been made to create an ethical infrastructure by taking into account the legal regulations that contain provisions related to the matter, and various international agreements or regulations where Turkey is a party, within the Turkish judicial system. In this framework, analysing the effort to create an ethical policy and system to contribute to the administrators' ethical decision-making process in Turkish public administration within the scope of regulations, institutional dimension and ethical codes is of great importance in terms of understanding the current ethical system that exists in the country.

The principles of ethical conduct to be followed by civil servants in Turkey are regulated by the basic principles set forth in the laws in force. In this context, it can be argued that the legal framework of the ethical foundations in public administration is broadly established first and foremost with the constitution, then with laws such as Law No 657 on Civil Servants, Law No. 5237 on the Turkish Criminal Code, Law No. 3628 Act on Declaration of Property and Fight with Bribe and Corruption, Law No 4982 on Right of Information Acquirement, Law No. 5018 on Public Financial Management and Control, Law No. 4734 on Public Procurement and with direct or indirect remarks to ethics in the articles of these laws (Yüksel, 2010, p. 263). However, the most fundamental step towards an effective ethics policy and towards the creation of an ethical foundation is Law No 5176 Related to the Establishment Council of Ethics for Public Service and Making Modifications on Some Laws, which was passed in 2004; and Regulation on the Principles of Ethical Behaviour of the Public Officials and Application Procedures and Essentials, published on the Official Gazette in 2005, which determined the ethical principles and standards that the civil servants had to abide.

In 2004, before the above-mentioned Law and the relevant Regulation was passed and the acceptance of Turkey to the European Union as a candidate country, the passing of a law regarding the ethical behaviour of civil servants seems to have been emphasised as part of the successive activities within the framework of the reconstruction attempts. In the "Action Plan for Strengthening Transparency and Enhancing Effective Public Administration", which was passed in 2002, factors such as introducing a law aimed at civil servants regarding ethical behaviour, establishing expert courts to fight corruption, stating the need for strengthened transparency in public administration as well as effectiveness and efficiency were explicitly stated (Başbakanlık, 2002). In the "Urgent Action Plan" as well, which was passed in 2003, there were regulations about fighting corruption, emphasising important public ethics concepts such as transparency, and accountability under the sub-topic "Fighting Corruption" (Başbakanlık, 2003). With the issuance of Law No 5176 Related to the Establishment Council of Ethics for Public Service and Making Modifications on Some Laws in 2004 and the "Regulation on the Principles of Ethical Behaviour of the Public Officials and Application Procedures 
and Essentials" in 2005, which determined the ethical principles and standards that the civil servants had to abide by, the fundamental legal foundation for the institutionalisation of an ethical system was created.

Actually, in creation of an ethical foundation and a policy as well as public opinion and public awareness, NGOs such as the Turkish Industry and Business Association (TÜSİAD), the Economic Policy Research Foundation of Turkey (TEPAV), the Turkish Economic and Social Studies Foundation (TESEV), the Social Transparency Movement Association (TSHD), which acts as part of Transparency International, and the Turkish Ethical Values Centre (TEDMER), the Government Supervision Personnel Association, Protecting the Taxes of Citizens (VAVEK), the White Point Foundation, and the Union of Chambers and Commodity Exchanges of Turkey (TOBB) have been just as effective as international institutions such as the EU, European Council, WB, IMF, and OECD (Demirci \& Genç, 2008, p. 51). Thus, the heavy effect of the international and civil actors on the institutionalisation and policy creation process regarding ethics can clearly be observed.

With Law No 5176, the legal regulation and institutional structure that will contribute to the ethical decision-making and ethical behaviours of civil servants have been clearly defined. A responsible board called the "Board of Ethics for Civil Servants" was founded with this regulation, and this Board has regulated the ethical principles that will shed light on civil servants' actions, procedures, and decisions with the regulation they have created. The Board is dependent on the Prime Ministry, is comprised of eleven members and the members' period in office is four years (Law No 5176, Art. 2). In accordance with the relevant Law, the Board "shall determine the ethical code of conduct that civil servants should abide by as they perform their duties with the regulations it shall prepare, shall report to the relevant authorities any ex-officio or applications by doing the necessary inquisition and investigation on the applications for alleged violation of ethical codes of conduct, and shall carry out activities or have them carried out to create an ethics culture in society, and support the work to be carried out in this regard" (Art. 3). The President, the members of the Parliament, the members of the Cabinet, members of the Turkish Armed Forces and the Judiciary, and Universities are out of the audit scope of the Board (Art. 1). The Board that is specified by the regulation can be consulted with the claim that public institutions and organisations have practices that are against ethical behaviour principles, and relevant institutions' authorised discipline boards can be consulted with the claim that other civil servants have practices that are against ethical behaviour principles (Art. 4). The Board shall carry out its inspection and investigation on the grounds that ethical codes of conduct have or have not been violated, and shall notify those concerned and the Prime Ministry in writing of the results of the inspection and the investigation (Art.5). The provision that states that if an unethical action is determined in the investigations carried out by the Board stated in Article 5 of the Law, the Board Decision regarding the topic shall be shared with the public through being published on the Official Gazette has been nullified through the Supreme Court's Decision dated 4/2/2010, No E.: 2007/98, K.: 2010/33 (Anayasa Mahkemesi Karar1 04.02.2010; 
2010/33). In the current situation, the Board informs those concerned and the Prime Ministry about the decisions it has taken about actions against the ethical codes of conduct and shares them with the public on its website without disclosing their personal information.

The Board works as a regulatory, supervisory and educational body. The Board has established in its regulation the ethical principles or codes that civil servants must comply with. It has the authority to inspect whether these principles or codes are being complied to within its audit scope of civil servants. Finally, by combining the educational activities with the training activities and the projects it organises, it fulfils its role, especially with the support of international organizations (Öztepe, 2013, p. 247).

Another regulation guiding the civil servants regarding ethical decisionmaking and ethical behaviour is that of ethical principles or codes. The Board of Ethics for Civil Servants has regulated the ethical principles that the civil servants have to abide by with "Regulation on the Principles of Ethical Behaviour of the Public Officials and Application Procedures and Essentials", decreed in 2005. Fundamental ethical principles that are adopted by the OECD and the European Commission have also provided the framework for the system created in Turkey. Elements that are regulated through many articles in Law No 657 on Civil Servants were counted among the ethical principles with the relevant regulation (Öztepe, 2013, pp. 224-258).

The aim of the Regulation is stated in the $1^{\text {st }}$ article as "to create an ethics culture in public, to set ethical codes of conduct that civil servants need to abide by while carrying out their duties, to assist the civil servants in behaving in accordance with these principles and to increase the public's trust in public administration by eliminating situations that create distrust in the society and damage justice, honesty, transparency and objectivity principles", and within the scope of this aim, the ethical behaviour principles or codes are regulated between the articles 5 to 22. According to this, when civil servants are performing their duties as well as when they are making decisions about their duties, they need to abide by the principles which are listed in the following table.

Table

\section{Duties of Civil Servants Regarding Ethical Behaviour Principles}

\begin{tabular}{|c|}
\hline Act consciously with public service in mind when fulfilling the duty \\
\hline Act with a consciousness towards public service \\
Compliance with service standards \\
Being loyal to the aim and the mission \\
\hline Honesty and objectivity \\
Reputability and accountability \\
Kindness and respect \\
\hline Notifying the competent authorities of unethical conduct and illegal activities \\
\hline
\end{tabular}




\begin{tabular}{|c|}
\hline Avoiding conflict of interests \\
\hline Not using duties and power for their own interests \\
\hline Prohibition of receiving gifts and taking advantage of their position \\
\hline Not using public goods and resources other than for public purposes and service requirements \\
\hline Avoiding lavishness \\
\hline Not making explanations that exceed one's authority and not making unrealistic statements \\
\hline Acting in compliance with the principles of giving information, transparency, and participation \\
\hline For managers to act within the framework of accountability \\
\hline Not giving any concessions or privileges in relations with former civil servants \\
\hline Notification of goods \\
\hline
\end{tabular}

Source: 13.04.2005 Tarihli ve 25785 Sayılı Kamu Görevlileri Etik Davranış İlkeleri ile Başvuru Usul ve Esasları Hakkında Yönetmelik Art. 5-22.

Additionally, in the $26^{\text {th }}$ Article of the Regulation, it is stated, "depending on the characteristics of the service or duty they are carrying out, the institutions and organisations are free to present their institutional behaviour principles to the Board's inspection and approval." A civil servant having to sign an ethical contract when starting public service is also one of the elements that have been edited with the relevant regulation. In the appendix part of the aforementioned regulation, the copy of the ethical contract and the civil servants, who are at least general managers, equals of general managers and seniors of general managers, within the ethics board's scope of authority have been arranged in detail. Finally, it is stated in the aforementioned regulation's provisions that "institutions and organisations will establish an ethics commission of at least three persons from within the institution selected by the general manager of the institution or organisation in order to create and develop the ethics culture, to recommend and guide the staff about the problems they encounter in ethical behaviour principles and to evaluate the ethical practices" (13.04.2005 ve 25785 Sayılı Kamu Görevlileri Etik Davranış İlkeleri İle Başvuru Usul ve Esasları Hakkında Yönetmelik Art. 29).

As is evident, it is possible to state that the necessary regulations are being implemented on the legislation, institutional structure and ethical principles bases to combat unethical activities through creating an ethical system and policy. However, it is observed that there are some problems with their implementations with regards to their efficiency and how much positive contribution they make. To sum up, when the aforementioned Board and the relevant regulation are evaluated together, it is observed that the primary objective is to create an ethical system under the name of ethical principles as a new application of many scattered provisions for civil servants that can be evaluated under the scope of ethics, and to realise institutional structures and regulations that will guide the civil servants in behaving ethically and making ethical decisions. However, as Arap and Yllmaz (2006, p. 53) pointed out, the regulations regarding the ethics board did not create a previously non-existent system of principles, rather, they have arranged the previously exis- 
tent principles, reinterpreting them within the framework of public administration. The fact that the Board is affiliated to the Prime Ministry and the fact that some civil servants are excluded from the scope of the audit by exemptions are other matters that are criticised regarding the regulations made. Particularly the exclusion of the Parliament and the political wing from the scope of the supervision is accompanied by the risk of making the Board vulnerable to oppression and influence from these bodies.

Another difficult situation is that ethical codes of conduct are arranged in a way that can be easily changed and left entirely to the regulations to be prepared by the initiative of the Board, and that some of the codes of ethical principles in the Regulation are not sufficiently clear and defined. In addition, the fact that the decisions made by the Ethics Committee are not judicial decisions so they do not have serious consequences, and that the Board finds it sufficient to notify the relevant bodies when it identifies any unethical situations are points that are criticised and that hurt the effectiveness of the Board (Midilli, 2004; TÜSİAD, 2005, p. 4; Arap \& Yilmaz, 2006). In the end, although there are some incomplete and criticised aspects, the ethical system created in light of the policies and regulations regarding ethics and ethical decision-making in Turkish public administration has created an ethical awareness, dispersed the concept of "public ethics", and has created a source for civil servants regarding ethical decision-making and avoiding unethical behaviours, even though its efficiency is debatable.

\section{Conclusion}

The importance of decision-making in shaping and implementing public policies is extremely high. As part of the public administration mechanism, which is the main instrument of public policy that has an important place in the sustainability of social life, managers have to make various decisions in order to implement such policies and keep the general operation of public administration smooth. One of the significant factors shaping this decision-making process is ethics. In short, ethics, which can be defined as a control mechanism, is a set of generalisations to control the behaviours of individuals in both individual and societal contexts, and affects the decision-making process on an individual or organisational basis. Public administrators have to consider the ethical dimensions of their decisions just as they should take into account many variables such as public benefit, equity, and justice.

It is observed that there are various institutional structures and ethical principles as well as legal regulations that will assist public administrators in the decision-making process in Turkey. In this context, it seems that significant steps have been taken in order to create an ethical structure in the struggle against corruption and degeneration in Turkish public administration. Legal legislation, institutional structure and ethical principles have been established, especially since the year 2000, when the policies, regulations and practices combating corruption and creating an ethical public administration begun to be realized. While these efforts are crucial steps taken to implement basic regulations that will help in the creation of an ethical public administration and ethical decision-making for civil servants, 
unethical activities are still observed. Ultimately, although significant steps have been taken and studies have been carried out at the point of prevention of corruption and unethical activities in Turkish public administration since 2004, when these processes became more tangible through regulations, it is not possible to say that an effective formation has taken place.

As a result, even though it is utopian that unauthorized activities and corruption in the public sector are totally absent, it is highly crucial to take necessary precautions at the point of minimizing such behaviours and activities. In this regard, precautions should be comprehensive and aimed at removing multiple components. Moreover, the measures should be designed with the dilemmas and difficulties that managers face during the decision-making process in mind. An understanding where the public interest is held above everything else and the moral responsibility is high should be integrated into the public administration discipline.

\section{REFERENCES}

1. Anayasa Mahkemesi, T.C. (2010). E.: 2007/98, K.:2010/33 Say1l ve 04.02.2010 Tarihli Anayasa Mahkemesi Kararı. Available at:http://www.resmigazete.gov.tr/eskiler/2010/05/20100518-20. htm (accessed: 22 May, 2018).

2. Anderson, J. E. (1979). Public Policymaking: An Introduction (2nd ed). New York: Holt, Rinehart and Winston.

3. Arap, İ. \& Yılmaz, L. (2006). Yeni Kamu Yönetimi Anlayışının "Yeni” Kurumu: Kamu Görevlileri Etik Kurulu. Amme İdaresi Dergisi, vol. 39, no 2, pp. 51-69.

4. Balcı, A. (2003). Kamu Yönetiminde Hesap Verebilirlik Anlayışı. In: Balcı, A., Nohutçu, A., Öztürk, N. K. And Çoşkun, B. (eds). Kamu Yönetiminde Çağdaş Yaklaşımlar, Ankara: Seçkin Yayınc1lik, pp. 115-133.

5. Başbakanlık, T. C. (2002). Türkiye’de Saydamlığın Artırılması ve Kamuda Etkin Yönetimin Geliştirilmesi Eylem Planı. Ankara.

6. Başbakanlık, T. C. (2003). Acil Eylem Planı. Ankara.

7. Birkland, T. A. (2005). An Introduction to the Policy Process: Theories, Concepts, and Models of Public Policy Making (2nd ed). New York: M. E. Sharpe.

8. Boatright, J. R. (2000). Ethics and the Conduct of Business (3rd ed.). New Jersey, Upper Saddle River: Prentice Hall.

9. Bommer, M., Gratto, C., Gravander, J. \& Tuttle, M. (1987). A Behavioral Model of Ethical and Unethical Decision Making. Journal of Business Ethics, vol. 6, no 4, pp. 265-280.

10. Browning, L. D., Sørnes, J. O., Sætre, A. S. \& Stephens, K. (2006). A Garbage Can Model of Information, Communication, Technology Choice. In: Schorr, A. and Seltmann, S. (eds). Changing Media Markets in Europe and Abroad: New Ways of Handling Information and Entertainment Content. Lengerich: Pabst Science Publishers, pp. 417-440. 
11. Cavanagh, G. F., Moberg, D. J. \& Velasquez, M. (1981). The Ethics of Organizational Politics. The Academy of Management Review, vol. 6, no 3, pp. 363-374.

12. Cohen, M. D., March, J. G. \& Olsen, J. P. (1972). A Garbage Can Model of Organizational Choice. Administrative Science Quarterly, vol. 17, no 1, pp. 1-25.

13. Cooper, T. L. (2001). Handbook of Administrative Ethics (2nd ed.). New York: Marcel Dekker

14. Curtin, L. L. (1979). The Nurse as an Advocate: A Philosophical Foundation for Nursing. Advances in Nursing Science, vol. 1, no 3, pp. 1-10.

15. Daft, R. L. (2010). Management (9th ed). Canada: South-Western, Cengage Learning.

16. Demirci, M. \& Genç, F. N. (2008). Türkiye’de Kamu Yönetimi Reform Sürecinde Etik Yapılanma. Amme İdaresi Dergisi, vol. 41, no 2, pp. 43-58.

17. Dubinsky, A. \& Loken, B. (1989). Analyzing Ethical Decision-Making in Marketing. Journal of Business Research, vol. 19, no 2, pp. 83-107.

18. Dye, T. R. (2008). Understanding Public Policy (12th ed). New Jersey, Upper Saddle River: Prentice Hall.

19. Emre, C. (2002). Kültürel Değerler, Ahlak ve Türkiye'de Kamu Yönetimi. Mülkiye Dergisi, vol. 26, pp. 1-21.

20. Etzioni, A. (1967). Mixed Scanning: A Third Approach to Decision Making. Public Administration Review, vol. 27, no 5, pp. 385-392.

21. Ferrell, O. C. \& Gresham, L. G. (1985). A Contingency Framework for Understanding Ethical Decision Making in Marketing. Journal of Marketing, vol. 49, no 3, pp. 87-96.

22. Forester-Miller, H. \& Davis, T. (1996). Practitioner's Guide to Ethical Decision Making. Available at: http://alabamacounseling.org/pdf/ACAguide.pdf (accessed: 17 January, 2018).

23. Fritzsche, D. J. \& Becker, H. (1984). Linking Management Behavior to Ethical PhilosophyAn Empirical Investigation. Academy of Management Journal, vol. 27, no 1, pp. 165-175.

24. Gaudine, A. \& Thorne, L. (2001). Emotion and Ethical Decision-Making in Organizations. Journal of Business Ethics, vol. 31, no 2, pp. 175-187.

25. Gosling, J. J. (2004). Understanding, Informing, and Appraising Public Policy. New York: Pearson.

26. Gül, H. \& Memişoğlu, D. (2007). Yapısal Değişim Sorunu Çerçevesinde Yönetsel Reform. In: Çukurçayır, M. A. and Gökçe, G. (eds). Kamu Yönetiminin Yapısal ve İşlevsel Sorunları. Konya: Çizgi Kitabevi, pp. 57-112.

27. Gündoğdu, Ö. Ş. (1999). Kentsel Çevre Estetiğinin Etik Açıdan İrdelenmesi. Unpublished Master's Dissertation, Ankara University, Ankara, Turkey.

28. Hill, M. (1997). The Policy Process in the Modern State (3rd ed). Hemel Hempstead Hertfordshire: Prentice Hall / Harvester Wheatsheaf.

29. Hogwood, B. W. \& Gunn, L. A. (1984). Policy Analysis for the Real World. New York: Oxford University Press.

30. Howlett, M. \& Ramesh, M. (1995). Policy Cycles and Policy Subsystems. Canada: Oxford University Press.

31. Hunt, S. \& Vitell, S. (1986). A General Theory of Marketing Ethics. Journal of Macromarketing, vol. 6, no 1, pp. 5-16. 
32. Jones, T. M. (1991). Ethical Decision Making by Individuals in Organizations: An IssueContingent Model. Academy of Management Review, vol. 16, no 2, pp. 366-395.

33. Kılavuz, R. (2003). Kamu Yönetiminde Etik ve Bir Sorun Alanı Olarak Yozlaşma. Ankara, Seçkin Yayıncılık.

34. Knoepfel, P., Larrue, C., Varone, F. \& Hill, M. (2007). Public Policy Analysis. Bristol: The Policy Press.

35. Kohlberg, L. (1969). Stage and Sequence: The Cognitive-developmental Approach to Socialization. In: Goslin, D. A. (eds). Handbook of Socialization Theory and Research. Chicago: Rand McNally, pp. 347-480.

36. Lindblom, C. E. (1959). The Science of Muddling Through. Public Administration Review, vol. 19 , no 2, pp. 79-88.

37. Lindblom, C. E. (1979). Still Muddling, Not Yet Through. Public Administration Review, vol. 39, no 6, pp. 517-526.

38. Lipsky, M. (1980). Street-Level Bureaucracy: Dilemmas of the Individual in Public Services. New York: Russell Sage Foundation.

39. Meeler, D. (n. d.). Five Basic Approaches to Ethical Decision-Making. Available at: http:// faculty.winthrop.edu/meelerd/docs/rolos/5_Ethical_Approaches.pdf (accessed: 25 January, 2018).

40. Midilli, A. (2004). Kamu Görevlileri Etik Kurulu. Available at: http://www.elegans.com.tr/ arsiv/67/haber018.html (accessed: 22 May, 2018).

41. Muzumara, P. M. (2018). Ethics, Morals and Values in Education. Pittsburg PA, Dorrance Publishing.

42. Nice, D. C. (1987). Incremental and Nonincremental Policy Responses: The States and the Railroads. Polity, vol. 20, pp. 145-156.

43. Ostrom, E. (1991). Rational Choice Theory and Institutional Analysis: Toward Complementarity. American Political Science Review, vol. 85, pp. 237-243.

44. Ostrom, E. (2007). Institutional Rational Choice: An Assessment of the Institutional Analysis and Development Framework. In: Sabatier, P. A. (eds.). Theories of the Policy Process (2nd ed.). Boulder: Westview Press, pp. 21-64.

45. Öztepe, M. C. (2013). Kamu Yönetiminde Etik Sorunu: Türk Kamu Yönetiminde Etik Sisteminin Eleştirel Çözümlemesi. Unpublished Doctoral Dissertation, Ankara University Institute of Social Sciences, Ankara, Turkey.

46. Pehlivan, İ. (1997). Yönetimde Etik Sorunu ve Kamu Yöneticisinin Etik Davranışları. 21. Yüzyılda Nasıl Bir Kamu Yönetimi Sempozyumu, Ankara: TODAİE Yayınları, 7-9 May.

47. Rawls, J. (1971). A Theory of Justice. Cambridge: Harvard University Press.

48. Simon, H. A. (1972). Theories of Bounded Rationality. In: McGuire, C. B. and Radner, R. (eds). Decision and Organization. Holland: North-Holland Publishing Company, pp. 161-176.

49. Solak, S. G. \& Sancak, H. Ö. (2015). Karar Verme Sürecinde Etik. In: Kırışık, F. and Önder, Ö. (eds). Kamu Yönetiminde ve Siyaset Biliminde Karar Verme. Ankara: DetayYayıncılık, pp. 313-326.

50. Stewart, J. (2009). Public Policy Values. New York: Palgrave Macmillan 
51. Trevino, L. K. (1986). Ethical Decision Making in Organizations: A Person-Situation Interactionist Model. Academy of Management Review, vol. 11, no 3, pp. 601-607.

52. TÜSİAD. (2005). Devlette Etikten Etik Devlete: Kamu Yönetiminde Etik. Ankara: Basın Bülteni, Özet Bulgular.

53. Van Mart, M. (1996). The Sources of Ethical Decision Making for Individuals in the Public Sector. Public Administration Review, vol. 56, no 6, pp. 525-533.

54. Wittmer, D. P. (2001). Ethical Decision-Making. In: Cooper, T. L (eds). Handbook of Administrative Ethics. New York: Marcel Dekker, pp. 481-508.

55. Wood, J. (2001). Ethical Decision Making. Journal of PeriAnesthesia Nursing, vol. 16, no 1, pp. 6-10.

56. Yıldız, M. \& Sobacı, M. Z. (2013). Kamu Politikası ve Kamu Politikası Analizi: Genel Bir Çerçeve. In: Yıldız, M. and Sobacı, M. Z. (eds). Kamu Politikası: Kuram ve Uygulama. Ankara: Adres Yayınevi, pp. 16-42.

57. Yüksel, C. (2010). Devlette Etik: Dünyada ve Türkiye’de Kamu Yönetiminde Etik, Yasal Altyapı ve Uluslararası Uygulamalar. İstanbul: Boğaziçi Üniversitesi Yayınevi.

58. 5176 Sayılı ve 25.05.2004 Tarihli Kamu Görevlileri Etik Kurulu Kurulması ve Bazı Kanunlarda Değişiklik Yapılması Hakkında Kanun. Available at: http://www.mevzuat.gov.tr/ MevzuatMetin/1.5.5176.pdf (accessed: 22 May,2018).

59. 5227 Sayılıve 15.07.2004 Tarihli Kamu Yönetiminin Temel İlkeleri ve Yeniden Yapılandırılması Hakkında Kanun Tasarısı. Available at: https://www.tbmm.gov.tr/kanunlar/k5227.html (accessed: 22 May, 2018).

60. 25785 Sayılı ve 13.04.2005 Tarihli Kamu Görevlileri Etik Davranış İlkeleri ile Başvuru Usul ve Esasları Hakkında Yönetmelik. Available at: http://www.mevzuat.gov.tr/Metin.Aspx? Mevzuat Kod =7.5.8044\&MevzuatIliski=0\&s (accessed: 22 May, 2018). 